\title{
The effect of Music Festivals on Perceived Destination Images
}

\section{Dr. Pimpika Thongrom}

A senior lecturer in Tourism department at Rajamangala University of Technology Thanyaburi (Ph.D. Tourism, MRes , M.A. Tourism and Hospitality Management).

\begin{abstract}
Music festival is one of the special event. It is a unique cultural event which continuously held on a particular place and time. It has been confirmed that music festivals can attract people to visit the destinations. Various researches have explored the potential of festivals in forming destination image. It has not been yet explored a link between the music festivals and image formation of the destination. The research aim is to examine the effect of music festivals on the perceived images of destinations. The objectives are to explore music festival in Thailand and to examine the perception of tourists towards destination image influenced by music festival. Five music festivals in Thailand were chosen as the research settings. The data were collected by conducting semi-structured interviews with tourists. The qualitative data are analysed using thematic analysis. The findings show that the destination images are influenced by the music festivals. The perceived images of the destination may similar to the existing images, while some may differ and transferable. The findings also show that the participants perceive images of the place differently during the music festival. The results can be applied to destination marketer in order to create or shape the destination images.
\end{abstract}

Keywords: Destination image, festival, music festival

\section{Introduction}

Destination image has been widely studied in tourism research for over the last decade. Due to it has been proved that it has an effect on the decision making process. As it is a major factor in the destination selection process of tourists. Destination image role is more than simply awareness in decision making process. A strong favourable image encourages people to visit. Many researchers suggest that a positive images can increase the number of visitors to the destination (Echtner and Ritchie, 1993) 
Recently, some studies link destination image with an event. It considers that event image can influence destination image (Erfurt and Johnsen, 2003). Music festival is also studied as the special event which helps generate the number of tourists to the particular places at the particular time. However, the link between the music festival and how the tourists perceived the destination image has not been yet explored.

\section{Literature review}

The literature on destination image, event, and music festival are explored. In order to understand the link between the areas. Then the image of event and the image of destination is reviewed.

\subsection{Destination image}

Destination image refers to perceptions and impressions, idea and feelings and also beliefs which individual has for a particular destination (Crompton, 1979; Tasci, 2009). The tourism study also widely discusses the role of destination image in the decision making process to visit the destination (Hunt, 1975). It is believed that destination image can motivate people to travel considered as a pull factor (Crompton, 1979). Images are important because it helps tourists pre-imagine the experience before making a choice (Hunt, 1975; Tasci and Gartner, 2007). The literature is particularly looked at image components (Dann, 1996; Gartner, 1993; Gunn, 1988) and how people perceive, create, interpret, and develop destination image (Beerli and Martin, 2004; MacKay and Fesenmaier, 2000). Gartner (1993) defined cognitive, affective and connative components. The cognitive image component refers to the facts represented by objects which can be evaluated and measured such as climate, infrastruture, and transportation. While the affective image component refers to subjective feelings about the object such as exciting, relaxing, and boring (Gartner, 1993). Lastly, connative image component refers to an action component built on both cognitive and affective stages. For instance, people imagine being on the beach in a sunny day. In addition, Echtner and Ritchie (1993) categorise image components into three different dimensions: attribute or holistic, functional or psychological, and common or unique. Some researches study destination image components and intention behaviour. Bigne Alcaniz et al. (2009) find that cognitive image influences intention to revisit, while affective image influences intention to recommend. Elliot et al. (2011) find that affective image has greater influence on tourist beliefs about a destination. 


\subsection{Destination Image Formation Agents}

Referring to Gunn (1989), destination image can also be developed at two levels, and organic image and induced image. Gartner (1993) develops eight image formation agents (see table 1.1). The eight formation agents categorise destination image from three main image formation agents: induced, autonomous, and organic. Induced formation agent include traditional forms of advertising for destination. There are 4 subgroups which involve information received from destination or travel agents. An autonomous agent refers to information from media or popular culture which provide information about the destination outside the destination promoter's control. However, it potentially creates images of destination. An organic agent is the actual visit or tourists' past experience (MacKay and Fesenmaier, 1997). This includes opinions of friends and family and wordof-mouth. An organic formation agents are also outside the destination marketer's control (Tasci and Gartner, 2007). In addition, people are likely to be aware of the biased information from destination marketers. Thus, it is believed that induced formation agents tend to have less credibility than the other two groups. On the other hand, autonomous and organic image formation agents supposedly provide unbiased sources of information.

Table 1.1. Gartner's eight agents of image formation

\begin{tabular}{|c|c|c|}
\hline Agent & Characteristics & Sources \\
\hline Overt induced I & $\begin{array}{l}\text { Traditional forms of advertising from } \\
\text { destination or tourism organizations }\end{array}$ & $\begin{array}{l}\text { Brochures and print } \\
\text { media advertising }\end{array}$ \\
\hline Overt induced II & $\begin{array}{l}\text { Information which is of interest in the } \\
\text { travel decision process but not directly } \\
\text { associated with a particular } \\
\text { destination area }\end{array}$ & $\begin{array}{l}\text { Received from destination } \\
\text { or travel agent, } \\
\text { wholesalers, and } \\
\text { organisations }\end{array}$ \\
\hline Covert induced I & $\begin{array}{l}\text { Use of a recognisable spokesperson } \\
\text { or celebrity through traditional forms of } \\
\text { advertising }\end{array}$ & $\begin{array}{l}\text { Television, radio, and print } \\
\text { fmedia advertising }\end{array}$ \\
\hline Covert induced II & $\begin{array}{l}\text { Second-party endorsement through } \\
\text { unbiased reports such as newspaper } \\
\text { articles }\end{array}$ & $\begin{array}{l}\text { Familiarisation tours for } \\
\text { travel writers or special } \\
\text { interest media groups }\end{array}$ \\
\hline Autonomous & $\begin{array}{l}\text { Destination area promoters have no } \\
\text { control over what appears in this } \\
\text { formation agent }\end{array}$ & $\begin{array}{l}\text { News and popular culture; } \\
\text { movies, feature films, } \\
\text { songs, art, and literature }\end{array}$ \\
\hline $\begin{array}{l}\text { Unsolicited } \\
\text { organic }\end{array}$ & $\begin{array}{l}\text { Information is not requested but is } \\
\text { offered in everyday conversation }\end{array}$ & $\begin{array}{l}\text { Friends and relatives who } \\
\text { have been to an area, or } \\
\text { believe they know what } \\
\text { exists there }\end{array}$ \\
\hline Solicited organic & $\begin{array}{l}\text { Information sourced by the individual } \\
\text { or group who has no interest in the } \\
\text { outcome of the decision }\end{array}$ & Word-of-mouth \\
\hline Org & tion or past experience & \\
\hline
\end{tabular}

Source: Gartner (1993)

News coverage and popular culture can provide substantial information about a place for a tourist. The literature confirms the relationship between image formation and the media, including music, literature and film (Thongrom, 2013). The Beatles connects their music with Liverpool city. Likewise, Hip-hop music creates the positive image to New York and Detroit (Xie et al., 2007). 
Recently, the researches find the link between event and destination image. Lai (2016) finds that the event image of Beijing Olympic Games has a strong effect of destination image. According to Gartner's image formation agents, an event can affect the destination in two basic ways. Firstly, it indirectly influences destination image by producing onsite event experiences and induced/ autonomous/ organic information for tourists. Secondly, it directly influences destination image through mental contracts such as perception, attitude, and image of the event. The researches show that the event image can change the destination image as it can be transferred (Kenyon and Bodet, 2018; Lai, 2016).

\subsection{Music Festivals}

The festival means a day or period of celebration, typically a religious commemoration. Now it refers to an organised series of concerts, plays, or movies, typically one held annually in the same place (Oxford Dictionary). The meaning concludes not only religious events but also cultural events for instance Woodstock, New York, USA and Cannes Film Festival, France.

The music festival refers to the event for holding the performance of singers and/or bands together rather than for a particular singer or band. Lashua and Spracklen (2014) describe that music festivals brought fans and bands together in one place.

Mostly, festivals are outdoor and provide food, drink, facilities, public toilets, and related products. Accommodation may or may not be provided. Moreover, festival refers to the continuously happen yearly at the same place. It can be either paid or free entry festival.

Music festivals can be held either one day or several day. It can be either for one or variety genres of music in one festival. For instance, Fuji Rock offers only Rock music bands. While Glastonbury offers Pop, Indy, Rock, Ragge, and Techno music. The music festivals in Europe and America often held in the summer time. While in Asia tend to hold in the cool season. However, there are some festivals, Pentaport Rick Festival in Korea, and Fuji Rock in Japan are in rainy season which become a unique image of the festivals. Moreover, these festivals are likely to locate in where can accommodate a large number of visitors.

Music festivals in Thailand are often held in cool season. Due to the summer season is too hot to have the festival outdoor. In the rainy season, there are more obstacles to set the venue outdoor. In this research studies 5 music festivals in Thailand. Big Mountain Music Festival was first held in February 2009 at Khao Yai, Nakhonratchasima Province. In 2013, it was moved to Kaeng Krajan, Phetchaburi Province. It is considered as the biggest and the best well known music festival in the country. This is a two-day-two-night festival held in December every year. There are main stage and smaller stages performed by singers and bands in different genres such as Pop, Hip Hop, Rap, Indy, Rock, Country and Techno. 
Overcoat Music Festival is located at Khao Ko, Phetchaboon Province since 2012. This one day music festival is held annually in December. The slop location provides audiences the good sight of the stage. The music genre for the festival is likely to be pop music.

Season of Love Song at Suan Pueng, Ratchaburi Province was first held in 2010. Its location was changed in 2013 but still in the same sub-district at Suan Pueng. The music which performs in the festival is mostly pop music and followed the theme of love song. This is a one day festival held in November every year.

Samed In Love is located on Samed Island, Rayong Province from 2013. This is a one day festival which used to be held in February then changed to May-June instead. Its location is unique on the white sand beach. The music played in the festival are various genres.

Pattaya Music Festival at Chonburi Province was first held in 2002 at North Pattaya. A year later the venue was expanded to South Pattaya. This is a three-day festival in summer season. It is held in March every year, except in 2012 which held in April. The festival is free entry as the event occupied the large area of the city of Pattaya.

\subsection{Music Festival impact on Tourism}

The studies link music festivals and tourist motivation and intention to visit. From the literature find that music festival motivate people to travel by the atmosphere and the activities in the festival. Also the desire to socialise with new people who share the same interest motivate people to visit the festival (Gelser and Robinson, 2009; Patterson and Peff, 2010: 96). Tomljenovie, Larsson and Faulkner (2001) add that people desire for pleasure and exciting experience. Bowen and Daniels (2005) find that 'discovery', 'music', and 'pleasure' are the important motivation to the tourists. More recent, Oh, Ahn and Back (2015) study the effects of Korean music via social media on the growth of inbound tourism in South Korea. Schabbing and Steffen (2012) confirm that music festival drawn number of tourist to visit. Nnamani (2014) adds that music festivals play vital roles in generating employment in Nigeria. Waitt and Duffy (2010) explore that music create emotional attachment to places at the study site of The Four Winds Festival. Likewise, Lashua and Spracklen (2014) examine how music transform particular places into tourist attractions. Their research highlight the relations between music, places, spaces and identities.

However, music festival can cause negative social, environmental and economical impacts to the destination. It can also have an effect on the image of destination either positive or negative. 


\section{Methodology}

The aim of this research is to understand how music festivals have an effect on the perceived destination image. This means it aims to understand people from the inside rather than through objective measurement. Consequently, a qualitative research approach is applied to this study

The research methodology follows the qualitative research approach. The data were conducted by the semi-structured interviews with 15 participants using purposive sampling. They must have been to any of the five selected music festivals. Each interview took between 30 to 60 minutes.

The criteria for music festivals choices as the research setting have been set as followed. It has to be held in a natural site; only music festival not including other Pop Culture activities; and continuously held at the same site at least 3 years. Five music festivals were selected 1) Overcoat Music Festival, Khao Koh; 2) Big Mountain Music Festival, Khao Yai; 3) Season of Love Song, Suan Pueng; 4) Samed in Love, Samed Island; and 5) Pattaya Music Festival, Pattaya. The research employ thematic analysis to analyse qualitative data from the interviews.

\section{Results}

The results show that the participant who visit the destination before visit the music festival have rather greater image of the destination. On the other hand, the participant who visit the music festival without prior visitation to the destination tend to transfer the event image to the destination image. While some images of event and destination emerge to the participant equally. There are 21 codes found during the analysis then the codes was developed into themes as follows (Table 1.2). 
Table 1.2 The perceived images of destination

\begin{tabular}{|c|c|c|}
\hline & Cognitive & Affective \\
\hline $\begin{array}{l}\text { Khao Koh } \\
\text { Overcoat Music Festival }\end{array}$ & \begin{tabular}{|l|} 
Cold \\
Less pollution \\
Expensive \\
Young to middle age visitor \\
Easy to access \\
Good location
\end{tabular} & \begin{tabular}{|l} 
Relax \\
Romantic \\
Not packed \\
Comfortable \\
Safe
\end{tabular} \\
\hline $\begin{array}{l}\text { Khao Yai } \\
\text { Big Mountain Music Festival }\end{array}$ & $\begin{array}{l}\text { Young visitor } \\
\text { Easy to access } \\
\text { Not expensive } \\
\text { Sex and drug } \\
\text { Not enough facilities }\end{array}$ & \begin{tabular}{|l} 
Party/ wild \\
Dirty \\
Fun \\
Freedom \\
Unsafe
\end{tabular} \\
\hline $\begin{array}{l}\text { Suan Pueng } \\
\text { Season of Love Song }\end{array}$ & \begin{tabular}{|l|} 
Family visitor \\
Varied attraction \\
Not far from Bangkok \\
Variety of accommodation \\
Not expensive
\end{tabular} & $\begin{array}{l}\text { Romantic } \\
\text { Relax } \\
\text { Safe }\end{array}$ \\
\hline $\begin{array}{l}\text { Samed } \\
\text { Samed in Love }\end{array}$ & \begin{tabular}{|l|} 
Limited accessibility \\
Hot \\
Dirty \\
Expensive \\
Alcohol \\
\end{tabular} & \begin{tabular}{|l|} 
Trapped \\
Wild party \\
Cool \\
Fun \\
Unique \\
\end{tabular} \\
\hline $\begin{array}{l}\text { Pattaya } \\
\text { Pattaya Music Festival }\end{array}$ & $\begin{array}{l}\text { Convenient } \\
\text { Easy access } \\
\text { Food and drink } \\
\text { Good music } \\
\text { Cheap }\end{array}$ & $\begin{array}{l}\text { International } \\
\text { Easy and comfortable } \\
\text { Safe }\end{array}$ \\
\hline
\end{tabular}

Khao Koh have been mentioned about its cold weather and less pollution air and easy to access. The size of the venue was also mentioned and link with 'not packed'. The perception of cost during and after the festival are varied. However, the cost of travel to Khao Koh is perceived as expensive and affordable for the particular age group of visitor from 25 to 45. Moreover, people connect relax and comfortable with sitting on the grass like picnic. Overcoat Music Festival has influence the image of Khao Koh which used to have a great image of fruit plantation and previous communist area.

Big Mountain Music Festival formed the image of young visitor, easy to access, and not expensive. The festival provides the van from Bangkok which run all day. The fare is not expensive and affordable travel cost for teenager. The age group of visitor is from 15 to 35 . However, the festival carries the image of sex and drug which links with fun, freedom and unsafe. The site is a very large area but lack of public toilet and trash bin. After the festival, there are pile of garbage which makes people perceived as dirty. However, the image of Khao Yai is perceived differently. The image of forest and national park is greater than music festival location. Thus the level of transfer the event image to the destination image is low. 
Suan Pueng is located not far from Bangkok and it is perceived as a family destination. It is also perceived that variety of attraction. Although there is no public transfer, the cost of travel is perceived as not expensive. Possibly, there are choices on accommodation cost. The image of romantic, relax, and safe are created together with the image of Season of Love Music Festival.

Samed in Love is perceived as unique because its location on the island. It is also linked to limited accessibility because of the ferry timetable. The visitors cannot travel whenever they prefer but have to follow the timetable. As it is located on the island the cost of living is higher than the mainland.

Pattaya's image and Pattaya Music Festival's image are not different. People perceived Pattaya as the place where are a lot of foreigners. There are vans run all day from Bangkok. There are choices of food and drink. The music which plays in the restaurants in Pattaya is at high standard. The music at the Pattaya Music Festival is variety on the main stage and smaller festival.

\section{Conclusion}

The image of event/ music festival and the image of destination can be transferred. In case that the images of music festival are greater, the images of destination can be changed. On the other hand, the images of destination are greater, like Khao Yai, the images of music festival are not influenced. It can be concluded that the music festival can be used as an image formation agent in order to create, formed and shaped the destination image.

\section{References}

Baloglu, S. and McCleary, K. W. (1999). A model of destination image formation. Annals of Tourism Research 26 (4), pp.868-897.

Beerli, A. and Martín, J. D. (2004). Factors influencing destination image. Annals of Tourism Research 31 (3), pp.657-681.

Bowen, H.E., and Daniels, M.J. (2005). Does the music matter? Motivations for attending a music festival. Event Management 9(3), pp. 1550164

Crompton, J. L. (1979). An Assessment of the Image of Mexico as a Vacation Destination and the Influence of Geographical Location Upon That Image. Journal of Travel Research 17 (4), pp.1823. 
Dujmovic, M. And Vitasovic, A. (2012). Festivals, Local Communities and Tourism. Soundtrack: Music, Tourism and Travel. 6-9 July, 2012, Liverpool, UK.

Echtner, C. M. and Ritchie, J. (1993). The Measurement of Destination Image: An Empirical Assessment. Journal of Travel Research (Spring), pp.3-13.

Fest300 magazine, June 30, 2015 'a (brief) 1,000 year of music festivals [online] Available from: https://www.fest300.com/magazine/a-brief-1000-year- history-of-music-festivals accessed by30 November 2015.

Gartner, W. (1993). Image Formation Process. In: Uysal, M. and Fesenmaier, D. (eds.) Communication and Channel Systems in Tourism Marketing. New York: Haworth Press, pp.191215.

Hunt, J. (1975). Image as a Factor in Tourism Development. Journal of Travel Research 13 (3), pp.17.

Kaplanidou, K. (2006). The impact of sport tourism event image on destination image and intentions to travel: a structural equation modelling analysis. Michigan State University. (Doctoral Thesis).

MacKay, D. and Fesenmaier, D. R. (2000). An Exploration of Cross-Cultural Destination Image Assessment'. Journal of Travel Research 38, pp.417-423.

Nnamani, S. (2014). Music and Tourism: Their Roles in Generating Employment in Nigeria. American Journal of Educational Research 2 (11), pp.1065-1068.

Oh, S., Ahn, J. \& Baek, H. (2015). The Effects of Social Media on Music-induced Tourism: A Case of Korean Pop Music and Inbound Tourism to Korea. Asia Pacific Journal of Information Systems 25 (1), pp. 121-134.

Ristivojevic, M. (2012). Belgrade on the New Wave Analysing the role of music in creating a city image. Soundtrack: Music, Tourism and Travel. 6-9 July, 2012, Liverpool, UK.

Schabbing, B. And Steffen, A. (2012). Classical music festival customers in Germany: a segmentation and comparative study of four major German music festivals. Soundtrack: Music, Tourism and Travel. 6-9 July, 2012, Liverpool, UK.

Tasci, A. D. A. (2009). Social Distance. Journal of Travel Research 47 (4), pp. 494-507.

Tomljenovic, R., Larsson, M., \& Faulkner, H. (2001). Predictors of Satisfaction with Festival Attendance: A Case of Storsjoyran Rock Music Festival. Tourism 49 (2), 123-132.

Thongrom, P. (2013). The effect of interpreted filmic signs on destination image through a consideration of semiotics (Doctoral thesis).

Waitt, G and Duffy, M. (2010). Listening and Tourism Studies. Annals of Tourism Research 37 (2), pp. $457-477$

Xie, P. F., Osumare, H. and Ibrahim, A. (2007). Gazing the hood: Hip-Hop as tourism attraction. Tourism Management 28 (452-460). 